Article

\title{
Multi-Faith Spaces Uncover Secular Premises Behind the Multi-Faith Paradigm
}

\author{
Ryszard Bobrowicz \\ Faculty of Theology, University of Copenhagen, Karen Blixens Vej 16, 2300 København, Denmark; \\ ryszard.bobrowicz@gmail.com; Tel.: +46-736-170-835
}

Received: 29 December 2017; Accepted: 22 January 2018; Published: 25 January 2018

\begin{abstract}
Multi-Faith Spaces (MFSs) are a relatively recent invention that has quickly gained in significance. On the one hand, they offer a convenient solution for satisfying the needs of people with diverse beliefs in the institutional context of hospitals, schools, airports, etc. On the other hand, MFSs are politically significant because they represent the cornerstone of the public religion in Europe today, that is, multi-faith paradigm. Due to their ideological entanglement, MFSs are often used as the means to promote either a more privatised version of religion, or a certain denominational preference. Two distinct designs are used to achieve these means: negative in the case of the former, and positive in the latter. Neither is without problems, and neither adequately fulfils its primary purpose of serving diverse groups of believers. Both, however, seem to follow the biases and main problems of secularism. In this paper, I analyse recent developments of MFSs to detail their main problems and answer the following question: can MFSs, and the underlying Multi-Faith Paradigm, be classified as a continuation of secularism?
\end{abstract}

Keywords: multi-faith spaces; secularisation; multi-faith paradigm; unaffiliated; multi-belief

\section{Introduction}

The notion of progressive "secularisation" has been an intellectual commonplace in Western Europe since at least the nineteenth century (Norris and Inglehart 2005, p. 3). Secularisation assumes that the processes of modernity will result in the final "disenchantment of the world" (Weber 1958, p. 133), and the gradual disappearance of religion will follow. As Jeffrey K. Hadden put it, "in due course the sacred shall disappear altogether except, possibly, in the private realm" (Hadden 1987, p. 598). However, systematic challenges put a strain on that theory (for Europe, see e.g., (Casanova 2006)). Already, Hadden claimed that secularisation was only an "orienting concept grounded in an ideological preference" (Hadden 1987, p. 587). Some, like Pippa Norris and Roman Inglehart, built upon this claim, asserting that its traditional version needs corrections, and should be considered a tendency rather than "iron law" (Norris and Inglehart 2005, p. 5). Others, like Peter Berger, took the critique even further, and argued that secularisation should be rejected as "essentially mistaken" (Berger 1999, p. 2).

A different perspective was offered by Ferrari (2012), who argued that secularisation was not only a descriptive, but also a normative concept. It served as a purposeful policy of making the public sphere truly neutral and impartial, which could only be achieved by making it secular, that is, by making all public decisions on the basis of rational rather than religious principles (p. 356). However, Ferrari claimed that secularism was not as neutral as it advertised itself. Quite the contrary, it favoured some religious traditions, while imposing constraints on the other (p. 359). Ferrari drew the line between "two different ways of conceiving and experiencing religion, [the favoured] one more focused on the forum internum and the other on the forum externum" (p. 367). These distinct ways led to two alternatives in thinking about religion, both equally unsustainable. Either the emphasis was put 
on the freedom of choice and the public sphere was accessible rather to those religions that based their membership solely on individual conscience, or the emphasis was put on the "identitarian and cultural value of religion", which reserved public sphere predominantly for traditional religion (p. 370).

Both alternatives are, however, unsustainable due to a rapid change in the religious landscape of Europe throughout the twentieth and the early twenty-first century. Factors such as an influx of migrants, the birth of New Age movements or the loosening of denominational association among many Christians resulted in the rising multi-religiosity and the development of non-institutional forms of religion (Davidsen 2012, pp. 554-55). Western Europe has the highest percentage of the unaffiliated, who account for more than half of its population (WIN-Gallup International 2012, p. 17). However, the majority of those still hold some religious beliefs (Hackett and Grim 2012, p. 24), with 77\% of Europeans believing in some spiritual reality (European Commission 2010, p. 381). This complexity will progress till 2050, when the Muslim, Hindu and Buddhist populations are forecasted to double (Hackett et al. 2015, p. 147).

The so-called "multi-faith spaces" were developed in response to this rising multi-religiosity. At first, these spaces were an answer to the diverse religious needs in the institutional context of public facilities, such as schools, hospitals and airports. Recently, however, Multi-Faith Spaces (MFSs) began to move away from such institutions and emerged as standalone projects. In Berlin, a priest, a rabbi and an imam decided to erect a joint church of three monotheistic religions under the name "House of One" (House of One 2017). More recently, Copenhagen City Hall allocated funds for the construction of the first multi-faith church (Nilsson 2016), and the first religion-neutral cemetery was created in Borlänge, Sweden (Ago 2016).

In this paper, I plan to review the developments of MFSs to date to detail their main problems, and, further, analyse the extra-institutional developments to answer the following questions: (1) does MFS theoretical orientation, a multi-faith paradigm, share common features with secularism; (2) do MFSs confirm that this paradigm is biased as Ferrari proposed; (3) do all of these spaces fall into the general trend? Due to the limited examples in Western Europe, I will focus on the three already introduced initiatives which seem to capture the two above-mentioned attitudes towards the multi-faith trend.

\section{Definition and Problems of Intra-Institutional MFSs}

Although some spaces were shared by different religions in the past, the phenomenon of the MFSs is quite recent. As Terry Biddington noted, the first explicitly all-inclusive "Andachtsraum" appeared at Vienna Airport only in 1988 (Biddington 2013, pp. 316-17). Because of their novelty, MFSs are still not well-defined. "The Multi-Faith Spaces" exhibition evidenced that even the naming convention was not congruent, ranging from "inter-faith chapels" to "retreat lounges" (Brand et al. 2012), which resulted from the efforts to attract wide audiences (Crompton and Hewson 2016, p. 83). MFSs are designated for various spiritual activities and should address both the religious and the non-religious needs, without a bias towards any worldviews. And while their emergence was a consequence of both grassroots initiatives and voluntary decisions of facilities' management, MFSs began to be promoted and recommended, among others, by government agencies in Europe (e.g., in the UK, see (Collins et al. 2007, pp. 168-70) or in Spain, see (Velasco 2011)).

There are no architectural guidelines for the construction and design of MFSs. Nonetheless, most of the existing spaces follow similar style patterns. Andrew Crompton (2013) noted that there were two basic types of MFSs: negative, shared by a majority of such places in Europe and the USA, and positive (p. 479). A "windowless white room with a few religious texts on a shelf and the paraphernalia of religion, when not actually in use, kept out of sight in boxes" (p. 474), all made from unobtrusive materials is the most common type of negative design. As Crompton argued, this is the architectural equivalent of an "ambient-noise" (p. 491). The positive style is often described as 'unity by inclusion', where the artefacts of different faiths are on display and the spaces are visibly occupied by different groups (p. 479). Regardless of their style, some MFSs are established in reappropriated Christian chapels, but most are built from scratch (The Economist 2013). 
The evaluation of MFSs varies significantly. On one hand, they are praised as the "new level of religious harmony" for their positive role in the facilitation of religious practice, the promotion of tolerance, and the balancing of religious and secular provisions (Crompton and Hewson 2016, p. 77). On the other, they often evoke equally strong negative reactions, especially regarding Islam. Some secularists accused MFS of serving as "hidden mosques" that "creep into the public spaces, cloaked behind political correctness" (The Economist 2013). Others see MFSs as a threat to their national values and traditional religion. This is why Marie Krarup, the Danish People's Party member of parliament, wanted to close a multi-faith retreat room at the Søndre Kampus of the University of Copenhagen (Ravn and Schmidt-Mikkelsen 2016). Meanwhile, many Muslims reject the multi-faith facilities, requesting for a dedicated space and, on some occasions, even protesting in the streets (Taneja 2010).

The problems seem to come from what Dinham (2012) called the muddle of the 'multi-faith paradigm', which concealed two contradictory understandings of religion. On the one hand, religions were treated as heroes of social cohesion that could bring different social groups together; on the other, as villains that radicalised individuals (p. 577). Thus, the multi-faith paradigm and the accompanying activities served a dual purpose: to use different religions to bring tolerance and a sense of togetherness, and, simultaneously, to fight religion, introducing a preference for a more privatised faith (p. 588).

Most MFSs tilt the scale towards the latter by adhering to the negative design. That is why Crompton and Hewson (2016) argued that MFSs "follow the modern preference for 'faith' rather than 'religion' and facilitate personal acts of worship", acting "as a benign form of social control, treating religion as a disorder to be tidied away" (pp. 80-81). However, such an approach generated multiple problems. Aiming at everyone resulted in a home to no-one and a sense of impermanence (p. 82). It put everyone at a disadvantage, but some more than others. Those, who needed objects, set activities and control over their surroundings in their religious practice, were discriminated against, while those who could pray anywhere were clearly favoured (p. 85). As Crompton and Hewson summed it up, "multi-faith design is a provisional business, an act of casuistry rather than synthesis. Although it aims at equality of opportunity users can never truly be served equally" (p. 84).

On top of that, a truly negative design is hard to achieve. As Velasco (2014) noted, a "neutral arrangement" gave the upper hand to the unaffiliated and the non-believers (p. 4). As an all-inclusive space, it needed an extreme amount of maintenance. Thus, based on several case studies, Diez de Velasco tried to develop guidelines for MFS administration. The rooms had to be spacious, soundproof and preferably circular, although a hexagonal design would work too. A scrupulous timetable should be maintained by an appointed inter-faith minister(s), as there should not be any simultaneous sharing by the groups. The rooms had to be spotlessly clean and the furniture easily removable for swift rearrangement of the carpets. However, even those rules did not solve all the problems that occurred amid increased religious activity, such as coincidental festivities of two religious groups (Velasco 2014, pp. 5-7).

In fact, the more distinctiveness MFSs accommodate, the better they work. This is well illustrated by a review of policies adopted by the UK universities. As Smith (2016) pointed out, they presented two different attitudes (p. 1). The best performing facilities, represented by most universities from the Russell Group, adopted the attitude of "pragmatism + public religion". They implemented the pragmatic recommendations of researchers like Diez de Velasco, introduced separate rooms for Muslim prayers, and recognised religion as an important and positive addition to their campuses, maintaining MFSs as a space for the cultural exchange (p. 5). On the other side of the spectrum were those spaces that promoted a more privatised faith, rejecting religion as an unnecessary and unwanted problem, with minimal, bland design and a lack of supervision (p. 8). They repeatedly gained negative media coverage due to the clashes between different faith groups and the perceived inadequacy to the needs of their users.

Hence, MFSs may achieve the opposite of what they aim for. At the very least, as Dinham pointed out, "multi-faith practices risk constituting a parallel world running alongside 'real' faith communities, 
seeming to respond to policy hopes but unable to bring constituencies of faith with them. To this extent, the multi-faith paradigm remains a construct of policy hopefulness" (Dinham 2012, p. 586). MFSs may generate conflicts and introduce inequality and discord. In the cases where former Christian chapels were converted, as Sophie Gilliat-Ray has noted, they may have even become a flashpoint of intra-institutional tension, especially between Christians, who were afraid of the exodus of their tradition, and Muslims, who use MFSs more often, due to their daily prayers (Gilliat-Ray 2005, p. 300).

Diaz de Velasco argued that, in fact, MFSs can be classified as part of "the diverse phenomena involved in redefining religious identities on an individual and collective scale that some have attempted to group beneath the umbrella term of secularization" (Velasco 2014, p. 3). And indeed, most of them fit well into Ferrari's definition of secularisation: they favour those religious beliefs that focus on the forum internum, and disadvantage those that entail external manifestation. Even though some MFSs serve as supplementary facilities for a social exchange, rather than a main place of religious observance, a vast majority of MFSs are organised around two notions: "choice" and "private religion". The "choice" lies behind the negative design, which embodies a reconfiguration of an old policy and hopefulness for secularism. On the contrary, "private religion" entails the positive design, a post-secular way to harmonise plurality of beliefs. Since the standalone MFS seem to be the next step of the multi-faith paradigm, they may rely on the experience of previously established spaces. This reliance will be the focus of the next section.

\section{Shift to Extra-Institutional MFSs}

In September 2016, Copenhagen City Hall agreed to allocate five million Danish crowns in their forthcoming budget for the building of what has been called by the media the first "Faith-Neutral Church" (Sputnik International 2016). The idea for what might better be named a ceremony room surfaced in 2008, in response to a recurring struggle of non-religious people for an alternative to the church and the town hall. A group of people proposed a neutral place for believers and non-believers alike, where they could celebrate various rituals and rites of passage in their favoured design (Voller 2008). A preliminary project of the facility was commissioned already in 2013, and Svendborg Architects proposed to convert the unused part of columbarium at the Bispebjerg Cemetery accordingly (Nilsson 2016).

The new building was designed as a 20-m high circular block, made of glass slats with a big window in the ceiling, and water seeping down from it for light to easily permeate the whole interior. The inside had to be neutral, and concurrently accommodating to everyone's needs. However, the reference to the church in media coverage was not ungrounded. As the architects admitted themselves, they were highly inspired by churches in their project, especially with regards to light, space, openness and acoustics. Like the religious temples, this building was designed to be both respectable and sublime (Faerch 2013).

While the "Ceremonirummet" is still in progress, its similarity to the intra-institutional MFSs is conspicuous. The preliminary design fits well into the "best practices" recommended by, among others, Diez de Velasco and Crompton. The building has a circular shape and is made of simple and neutral materials, with a good lighting and easily reconfigurable interior. With references to nature in the form of water, it constitutes a perfect example of MFS negative design. Moreover, with the religiously unaffiliated as the main group of potential users in mind, it even embodies the idea behind such spaces-a visible preference for an individual choice and faith rather than religion.

Stora Tuna Cemetery in Borlänge, Sweden, is a religion-neutral burial ground of a similar character. The local teacher applied for its foundation to the Church of Sweden, which, while no longer a part of Swedish State, still retains some public responsibilities, like provision and maintenance of burial grounds (The Local 2016). In spring 2016, all details were agreed upon and part of the cemetery was dedicated for a new, neutral graveyard. It is maintained by the local parish, which is not otherwise involved. And, again, negative design is the method of choice for the open character of the space. Everyone, regardless of own belief, is entitled to having their resting place there, 
as long as they refrain from exhibiting any religious, ideological or nationalist symbols on custom tombstones (Mankefors 2016). Those who want to be buried at a new ground can use a mortuary chapel, and have access to the fully optional regular service of a priest. Although the space is currently empty, the cemetery authority has already noted high interest (Ago 2016).

Scandinavian examples come from countries that either still have (Denmark) or, until very recently, had (Sweden) state churches that for a long time had a decisive voice in the sphere of public religion. This is where, according Peter Lüchau, the 'Scandinavian Paradox' emerged from: although the population of Scandinavia is deeply secular when it comes to beliefs, the membership rates in the national churches are very high (Lüchau 2009, p. 177). The new initiatives aim to counteract this paradox and make place for the rising numbers of "unaffiliated". It was especially clear in the "Ceremonirummet" case, whose initiators, for that very reason, wanted to secure at least partial state funding (Faerch 2013). Concurrently, one of the project's main supporters, The Danish Atheistic Society, ran a campaign encouraging renouncement of church membership (Sputnik International 2016).

However, while these initiatives counteract the influence of national churches, they can have a paradoxical effect. As Flemming Pless, a Christian vicar from Christianshavn in Copenhagen has noted, soon, at last, there will be an alternative for those who want to mark important transitions without reference to God and Christian tradition. Thus, he will no longer be obliged to enable it in his church (Bangslund 2016). This solution not only liberates people from the church domination, but also sets churches free from the state-imposed obligations.

In Germany, multi-faith movements have different character and aims than in Scandinavia, due to historical differences between their religious landscapes. For most of modern history, the latter was almost uniquely Lutheran, while the former has been religiously plural. Already in 1524, the first "Simultankirche" was erected in Bautzen for the shared use of Catholic and Protestants, and in 1732 the King of Prussia set up an Islamic Prayer room in Potsdam (Biddington 2013, p. 316). Later, the trauma of the Second World War only strengthened the need for tolerance and an inter-religious cooperation. This laid firm foundations for the so-called "House of One", which emerged in 2011 as a grassroots initiative of representatives from the three religious communities: Evangelical Parish of St. Petri-St. Marien, Jewish Community of Berlin and the Muslim initiative for dialogue Forum Dialogue e.V. While the funds are still being collected, its architectural basis has already been chosen in an international competition in 2012. Contrary to the above-mentioned spaces, it employs a positive design to harbour three distinct temples under one roof: a Christian Church, a Jewish Synagogue, and a Muslim Mosque, accompanied with a communal room, designated for inter-faith meeting space. Thus, every religion has its own place and is respected for its distinctiveness, but remains open to "the others" and common dialogue (House of One 2017). Therefore, it is not fully inclusive, like most MFSs, but rather focuses on certain religious traditions and adheres to the needs of the local population.

Although this will be the first building to house three temples at once, similar designs were introduced in the past. Crompton showed two such examples: Brandeis University, where Catholic, Protestant and Jewish Chapels stood side by side around a pool, and Coventry University Hospital, where separate mono-faith rooms for Catholic, Anglican, Hindu, Sikh and Muslim visitors are joined by a hallway, which, as Crompton suggested, became a true multi-faith space. As the distinctiveness of all these religions is satisfied, believers are more inclined to contact each other. These distinct spaces "begin to resemble each other" to the extent that they become "difficult to tell apart" (Crompton 2013, p. 486). The same principle applies to the "House of One". While the distinction of three religions is ensured by individual architectural form, the general aesthetics and building materials of the respective spaces remain the same.

Both the "House of One" and the "Ceremonirummet" are still in the conceptual phase. Despite their contradictory designs, it is hard to determine if they will suffer from the design-specific problems of the intra-institutional MFSs. The religion-neutral cemetery, an already functioning space of negative design, has run without problems so far. Unlike the intra-institutional MFS, these spaces have a supplementary character. Therefore, while they follow the general directions of MFSs in Europe, these 
spaces, contrary to their often-muddled predecessors, clarify two distinct purposes, both founded upon the notion of "distinction". On one hand, the negative design is introduced in those places where the unaffiliated and the believers need to be distinguished from the mix of a "traditional religion". On the other, the positive design is used to enforce the cohesion between already distinct religious traditions. The future research should address the following question: will extra-institutional MFSs influence the public debate? It seems that their introduction may have a three-fold outcome. They may either (1) polarise the public debate into the pro and contra-religious, (2) discharge the tension and transform the state-entangled religions, or (3) fail to enter the public debate.

\section{Conclusions}

Peter Berger argued that "modernity is not necessarily secularizing; it is necessarily pluralizing" (Berger 2008, p. 23). However, as I aimed to show in this paper, the general direction of the majority of MFSs in Europe strives to make these two notions interchangeable. With the increasingly plural Europe, the original form of secularism became unsustainable. Thus, to a certain extent, it was transformed into the "multi-faith" secularisation, or, in other words, "Secularism 2.0". By adherence to privatised faith rather than to organised religion, negative MFSs became a new form of disenchantment, confirming and bringing out the biases noted by Ferrari.

However, some spaces present a different attitude towards the multi-faith paradigm. A positive design is employed to facilitate openness and mutual understanding of religious traditions' distinctiveness. While the new standalone initiatives draw upon their predecessors, and do not introduce any revolutionary solutions, their supplementary character alleviates potential tensions. As they can openly support either individualised faith or religious traditions, they receive a new character and clarify two distinct attitudes towards MFSs. The difference between these attitudes is so big that it calls for their separation. Accordingly, two alternative names could substitute the term of "multi-faith spaces": the "multi-belief spaces" for the negative design (Velasco 2014, p. 2) and the "multi-religious spaces" for the positive design.

Unlike Dinham, I would argue that the notion of "multi-faith paradigm" is not a muddle, but rather an umbrella term for the transformations within the religious landscape of Europe. Crompton argued that "multifaith is politically significant because it is replacing Christianity as the face of public religion in Europe" (Ferrari 2012, p. 493). Indeed, both attitudes towards religion, described by Ferrari, seem to change accordingly. The emphasis on choice and individual conscience became a part of this paradigm, and the privilege and domination of the traditional religions seem to fade away. Is it possible that the latter will be replaced by an inter-religious cooperation? Are the positive and the negative design bound to ultimately clash? These questions would require further investigation.

Acknowledgments: I would like to thank Diana Edelman from the University of Oslo for her helpful comments on the main idea behind that paper, as well as Katarzyna Bobrowicz from the Lund University, who helped me with an extensive edition of the text, and Rhiannon Garth Jones from the University of Copenhagen, for linguistic comments. I would also like to acknowledge all people taking part in our ongoing project "In the Search for a Truly Multi-Faith Space", especially Moa Karlsson from the Lund University and Rúna Højgaard from the University of Copenhagen for all of the discussions on the described problems. I want to extend my gratitude to Mette Birkedal Bruun, the director of the Centre for Privacy Studies (PRIVACY) at the University of Copenhagen, and Michala Brechling, senior consultant at the KU PLUS, UCPH Innovation Hub, for affiliating the above-mentioned project. Finally, I would like to thank Terry Biddington from the University of Winchester for an encouraging correspondence.

Conflicts of Interest: The author declares no conflict of interest.

\section{References}

Ago, Niko. 2016. Här Finns Landets Första Neutrala Begravningsplats. SVT Nyheter. Available online: http: / / www.svt.se/nyheter/lokalt/dalarna/har-finns-landets-forsta-neutrala-begravningsplats (accessed on 28 December 2017). 
Bangslund, Af Louise. 2016. Radikale Vil Have Trosneutralt Ceremoni-Rum I København. TV 2 Lorry. Available online: http://www.tv2lorry.dk/artikel/radikale-vil-have-trosneutralt-ceremoni-rum-i-koebenhavn (accessed on 29 December 2017).

Berger, Peter L. 1999. The Desecularisation of the World. Resurgent Religion and World Politics. Grand Rapids: William B. Eerdmans Publishing Company.

Berger, Peter L. 2008. Secularisation Falsified. First Things 180: 23-27.

Biddington, Terry. 2013. Towards a Theological Reading of Multifaith Spaces. International Journal of Public Theology 7: 315-28. [CrossRef]

Brand, Ralf Gregor, Andrew Crompton, and Chris Hewson. 2012. Multifaith Spaces-Symptoms and Agents of Religious and Social Change. The University of Manchester and The University of Liverpool. Available online: http:/ / cargocollective.com/wwwmulti-faith-spacesorg (accessed on 27 December 2017).

Casanova, José. 2006. Religion, European Secular Identities, and European Integration. In Religion in an Expanding Europe. Edited by Timothy A. Byrnes and Peter J. Katzenstein. Cambridge: Cambridge University Press, pp. 65-92.

Collins, Peter, Simon Coleman, Janne Macnaughton, and Tessa Pollard. 2007. NHS Hospital 'Chaplaincies' in a Multi-Faith Society. The Spatial Dimension of Religion and Spirituality in Hospital. Durham: Durham University and NHS.

Crompton, Andrew. 2013. The Architecture of Multifaith Spaces: God Leaves the Building. The Journal of Architecture 18: 474-96. [CrossRef]

Crompton, Andrew, and Chris Hewson. 2016. Designing Equality: Multi-Faith Space as Social Intervention. In Religion, Equalities, and Inequalities. Edited by Sonya Sharma, Dawn Llewellyn, Pink Dandelion and Kristin Aune. London and New York: Routledge.

Davidsen, Markus Altena. 2012. Future Directions in the Sociology of Non-Institutional Religion. Implicit Religion 15: 553-70. [CrossRef]

Dinham, Adam. 2012. The Multi-Faith Paradigm in Policy and Practice: Problems, Challenges, Directions. Social Policy and Society 11: 577-87. [CrossRef]

European Commission. 2010. Biotechnology. Eurobarometer, 73.

Faerch, Michelle. 2013. En Ny Bygning Til Fødsel, Frieri Og Farvel-Men Uden Gud. Information. Available online: https: / /www.information.dk/kultur/2013/10/ny-bygning-foedsel-frieri-farvel-uden-gud (accessed on 20 December 2017).

Ferrari, Silvio. 2012. Law and Religion in a Secular World: A European Perspective. Ecclesiastical Law Journal 14: 335-70. [CrossRef]

Gilliat-Ray, Sophie. 2005. From 'Chapel' to 'Prayer Room': The Production, Use, and Politics of Sacred Space in Public Institutions. Culture and Religion 6: 287-308. [CrossRef]

Hackett, Conrad, and Brian J. Grim. 2012. The Global Religious Landscape. Washington: Pew Research Center.

Hackett, Conrad, Phillip Connor, Marcin Stonawski, and Vegard Skirbekk. 2015. The Future of World Religions: Population Growth Projections, 2010-2050, Demographic Study. Washington: Pew Research Center.

Hadden, Jeffrey K. 1987. Toward Desacralizing Secularization Theory. Social Forces 65: 587-611. [CrossRef]

House of One. 2017. Available online: https:/ / house-of-one.org/en (accessed on 20 December 2017).

Lüchau, Peter. 2009. Atheism and Secularity: The Scandinavian Paradox. In Atheism and Secularity. Edited by Phil Zuckerman. Santa Barbara, Denver and Oxford: ABC-CLIO, pp. 177-96.

Mankefors, Linda. 2016. Här Får De Neutrala Den Sista Vilan. DT. Available online: http:/ / www.dt.se/dalarna/ borlange/har-far-de-neutrala-den-sista-vilan (accessed on 20 December 2017).

Nilsson, Kirsten. 2016. København Kan Få En Kirke Uden God. Politiken. Available online: http://politiken.dk/ indland/article5635381.ece (accessed on 20 December 2017).

Norris, Pippa, and Ronlad Inglehart. 2005. Sacred and Secular. Religion and Politics Worldwide. Cambridge: Cambridge University Press.

Ravn, Tue, and Mia Schmidt-Mikkelsen. 2016. Taking Christianity Hostage. Universitetsavisen. Available online: http:/ / universitypost.dk/article/taking-christianity-hostage (accessed on 22 December 2017).

Smith, Jonathan D. 2016. Multi-Faith Muddle: Trends in Managing Prayer Spaces at UK Universities. Available online: https:/ / www.academia.edu/27658595/Multi-Faith_Muddle_Trends_in_Managing_Prayer_Spaces_ at_UK_Universities (accessed on 21 December 2017). 
Sputnik International. 2016. Copenhagen Gives Go-Ahead to God-Free Faith-Neutral Church. Sputnik International. Available online: https:/ / sputniknews.com/art_living/201609131045252355-danmark-religion-neutrality / (accessed on 20 December 2017).

Taneja, Poonam. 2010. Muslim Students in London University Prayer Room Row. BBC News. Available online: http:/ / news.bbc.co.uk/2/hi/uk_news/england/london/8598455.stm (accessed on 20 December 2017).

The Economist. 2013. God's New Digs. The Economist. Available online: http://www.economist.com/news/ international/21573967-best-multifaith-prayer-rooms-are-those-where-architects-bow-out-gods-newdigs (accessed on 20 December 2017).

The Local. 2016. Sweden Gets Its First Cemetery Free of Religious Symbols. The Local. Available online: http:/ / www.thelocal.se/20161019/ sweden-gets-its-first-cemetery-free-of-religious-symbols (accessed on 21 December 2017).

Weber, Max. 1958. Science as a Vocation. Daedalus 87: 111-34.

Velasco, Francisco Diez de. 2011. Guía Técnica Para La Implementación Y Gestión De Espacios Multiconfesionales. Madrid: Observatorio del Pluralismo Religioso en España.

Velasco, Francisco Diez de. 2014. Multi-Belief/Multi-Faith Spaces: Theoretical Proposals for a Neutral and Operational Design. RECODE, 26.

WIN-Gallup International. 2012. Global Index of Religiosity and Atheism. WIN-Gallup International. Available online: http:/ / www.wingia.com/web / files/news/14/file/14.pdf (accessed on 20 December 2017).

Voller, Louise. 2008. Ceremonier Uden Religion Til Folk, Der Lever Uden Gud. Information. Available online: https:/ / www.information.dk/kultur/2008/08/ceremonier-uden-religion-folk-lever-uden-gud (accessed on 22 December 2017).

(C) 2018 by the author. Licensee MDPI, Basel, Switzerland. This article is an open access article distributed under the terms and conditions of the Creative Commons Attribution (CC BY) license (http:/ / creativecommons.org/licenses/by/4.0/). 